\title{
Adolescent Perceptions of Large-Scale Social Distancing Policies
}

\author{
Seno Budhi Ajar \\ Universitas Sebelas Maret \\ senobudhiajar@staff.uns.ac.id
}

Article History

accepted 31/08/2020

approved 22/09/2020

published 28/10/2020

\begin{abstract}
The purpose of this study is to determine the perceptions of adolescence towards large-scale social distancing based on the adaptation typology of Robert K. Merton and to know the potential for deviations by late adolescents during large-scale social distancing. This research uses descriptive quantitative method. The sampling technique used purposive sampling where the sample taken was adolescents aged 17-20 years. Data collection techniques in this study using a questionnaire. The data analysis technique used is descriptive and percentage techniques. Based on the research results it can be concluded, first, that all respondents have positive perceptions of large-scale social distancing. This can be seen from the results is $82.67 \%$ of respondents chose conformity. $9.33 \%$ of respondents chose innovation, and $8.00 \%$ of respondents chose ritualism. Second, the potential factor causing the deviation is economic factors, the desire to exercise and the effectiveness of the implementation of large-scale social distancing.
\end{abstract}

Keywords: Large-Scale Social Distancing, Adaptation Typology Of Robert K, Deviation

\begin{abstract}
Abstrak
Tujuan penelitian ini adalah (1) mengetahui persepsi remaja akhir terhadap pembatasan sosial berskala besar (PSBB) berdasarkan tipologi adaptasi Robert K.Merton, (2) mengetahui potensi penyimpangan yang dilakukan remaja akhir pada saat pembatasan sosial berskala besar (PSBB). Penelitian ini menggunakan metode deskriptif kuantitatif. Teknik pengambilan sampel menggunakan purposive sampling dimana sampel yang diambil adalah remaja akhir yang berumur 17-20 tahun. Teknik pengumpulan data dalam penelitian ini terdiri adalah kuisioner. Teknik analisis data yang digunakan adalah teknik deskriptif dan persentase. Berdasarkan hasil penelitian dapat disimpulkan, pertama, bahwa seluruh responden mempunyai persepsi positif terhadap pembatasan sosial berskala besar (PSBB), hal ini terlihat dari hasil persentase responden dimana $82,67 \%$ responden memilih konformitas. 9,33\% responden memilih innovation, dan $8,00 \%$ responden memilih ritualisme. Kedua, potensi penyimpangan akan terjadi apabila terjadi tiga faktor yaitu faktor terkait faktor ekonomi untuk pemenuhan kebutuhan hidup, keinginan untuk berolahraga dan efektivitas penerapan pembatasan sosial berskala besar (PSBB)
\end{abstract}

Kata kunci: PSBB, Tipologi Adaptasi, Penyimpangan

Social, Humanities, and Education Studies (SHEs): Conference Series https://jurnal.uns.ac.id/shes

p-ISSN 2620-9284

e-ISSN 2620-9292 


\section{PENDAHULUAN}

Alexander (2013) menjelaskan mengenai manajemen pasca krisis untuk pencegahan penyebaran Covid-19. terdapat 3 (tiga) tahap yaitu:

1. Proteksi dan antisipasi. Tahap berupa perlindungan kepada masyarakat yang terkena dampak dan antisipasi terhadap keberlanjutan krisis.

2. Restorasi. tahapan restorasi dengan waktu yang tepat dan cepat untuk mewujudkan kembali kehidupan normal.

3. Formulasi. Yaitu tahapan dimana memformulasikan tujuan bersama dari semua pihak yang terlibat ataupun yang terkena dampak.

Salah satu cara yang dilakukan pemerintah pada tahap proteksi dan antisipasi adalah pembatasan fisik dan sosial, Pada tanggal 1 april 2020, Presiden Joko Widodo mengeluarkan kebijakan PSBB atau Pembatasan Sosial Berskala Besar. Kebijakan ini bertujuan untuk mengantisipasi agar penyebaran virus covid-19 dapat ditekan sehingga diharapkan mampu melindungi masyarakat dari penularan virus covid-19. Berdasarkan Peraturan Mentri Kesehatan Nomor 9 Tahun 2020 tentang Pedoman Pembatasan Sosial Berskala Besar Dalam Rangka Penanganan Corona Virus Disease 2019 pasal 13 menyatakan bahwa ada 6 (enam) komponen yang dibatasi dalam Kebijakan Pembatasan Sosial Berskala Besar meliputi:
a. peliburan sekolah dan tempat kerja;
b. pembatasan kegiatan keagamaan;
c. pembatasan kegiatan di tempat atau fasilitas umum;
d. pembatasan kegiatan sosial dan budaya;
e. pembatasan moda transportasi; dan
f. pembatasan kegiatan lainnya khusus terkait aspek pertahanan dan keamanan.

Kebijakan ini membuat masyarakat harus berada di rumah dan membatasi aktivitas mereka di luar rumah. Perubahan aktivitas ini membuat masyarakat harus beradaptasi. Proses adaptasi ini ada yang menanggapi secara positif tetapi adapula yang menanggapi secara negatif. Adaptasi dan penyesuaian diri selalu mempunyai akibat positif. Perlu diperhatikan satu factor social dapat mempunyai akibat negative terhadap fakta social lain (Ritzer, 2004). Terdapat lima pola dalam adaptasi sosial individu terhadap situasi tertentu. Yaitu :

Tabel 1. Tipologi Adaptasi menurut Merton

\begin{tabular}{lcc}
\hline Pola Adaptasi & $\begin{array}{c}\text { Tujuan Institusional } \\
\text { Masyarakat }\end{array}$ & $\begin{array}{c}\text { Cara Institusional } \\
\text { Masyarakat }\end{array}$ \\
\hline Konformitas & Terima & Terima \\
Inovasi & $(+)$ & $(+)$ \\
Ritualisme & Terima & Tolak \\
& $(+)$ & $(-)$ \\
Ritualisme & Tolak & Terima \\
& $(-)$ & $(+)$ \\
Rebelion & Tolak & Tolak \\
& $(-)$ & $(-)$ \\
& Tolak lama dan terima baru & Tolak lama dan terima baru \\
& $( \pm)$ & $( \pm)$ \\
\hline
\end{tabular}


1. Konformitas, Pada cara adaptasi ini sikap seseorang mengikuti cara dan tujuan yang telah ditetapkan oleh masyarakat.

2. Inovasi Merupakan cara seseorang berperilaku mengikuti tujuan yang ditetukan masyarakat tetapi memakai cara yang dilarang oleh masyarakat.

3. Ritualisme, Pada pola adaptasi ini, seseorang bersikap meninggalkan tujuan budaya, tetapi masih berpegangan pada cara yang telah ditetapkan oleh masyarakat.

4. Ritualisme dalam bentuk adaptasi ini seseorang bersikap tidak mengikuti tujuan budaya serta tidak mengikuti cara untuk meraih tujuan budaya.

5. Rebellion, Pada bentuk adaptasi ini seseorang tidak lagi mengakui struktur sosial yang berlaku serta berupaya menciptakan struktur sosial baru.

Kebijakan ini pasti mempengaruhi seluruh elemen masyarakat, tidak hanya dewasa tetapi juga anak-anak dan remaja. Remaja akhir mengalami pubertes dimana produksi hormon cukup tinggi dibandingkan fase yang lain. Karena Fase ini produksi hormon cukup tinggi, fase ini harus melakukan banyak aktivitas dan kegiatan. Masa adolesen sebagai masa remaja akhir umumnya antara usia 18-21 tahun (Fatmawaty : 2017). Karakteristik remaja akhir memiliki struktur dan pertumbuhan reproduktif hampir komplit dan remaja telah matang secara fisik, Fase ini mampu memandang masalah secara komprehensif dengan identitas intelektual sudah terbentuk. Serta telah memiliki stabilitas harga diri dan definisi terhadap citra tubuh serta peran jender hampir menetap. (Wulandari : 2014).

Permasalahan yang diajukan didalam artikel ini adalah untuk melihat bagaimana persepsi dan adaptasi terhadap Kebijakan Pembatasan Sosial Berskala Besar (PSBB) dan Faktor apa yang berpotensi menyebabkan remaja akhir melakukan penyimpangan pada kebijakan Pembatasan Sosial Berskala Besar (PSBB). Indicator prilaku penyimpangan yang digunakan adalah non conform maksudnya adalah prilaku yang tidak sesuai dengan nilai dan norma yang ada (nawarko dan bagong:2005) dalam hal ini nilai dan norma sesuai dengan Permen Nomor 9 Tahun 2020 tentang Pedoman Pembatasan Sosial Berskala Besar Dalam Rangka Penanganan Corona Virus Disease

\section{METODE}

Pada penelitian ini menggunakan pendekatan kuasi kuantitatif dengan menggunakan tipologi merton sebagai dasar penelitian. Metode penelitian ini menggunakan metode deskriptif, dengan data yang dibutuhkan adalah data primer yang diambil dari 80 responden dengan menggunakan kuisioner dalam pengumpulan data primer tersebut. Teknik analisis yang digunakan adalah Teknik persentase untuk menganalisis persepsi dan adaptasi remaja akhir dalam kebijakan Pembatasan Sosial Berskala Besar (PSBB) dengan tipologi adaptasi merton sebagai dasarnya sehingga membagi persepsi menjadi 5 pola yaitu konformitas, inovasi, ritualisme, ritualisme, dan rebelion, sedangkan untuk menjawab faktor-faktor yang dapat menimbulkan potensi penyimpangan pada remaja akhir terkadap kebijakan Pembatasan Sosial Berskala Besar (PSBB) menggunakan teknik analisis deskriptif.

\section{HASIL DAN PEMBAHASAN}

\section{Persepsi dan Pola Adaptasi Remaja Akhir}

Remaja akhir dalam bersikap terhadap kebijakan Pembatasan Sosial Berskala Besar (PSBB) sangat positif ataupun menerima baik tujuan maupun caranya. Persepsi positif tersebut dapat terlihat dari seluruh responden tidak ada yang memilih retretisme ataupun rebelion yang memiliki persepsi negatif atau menolak kebijakan Pembatasan Sosial Berskala Besar (PSBB). Pola adaptasi remaja akhir terhadap kebijakan 
Pembatasan Sosial Berskala Besar (PSBB) didominasi oleh konformitas, dan Sebagian kecil terdapat inovasi dan retretisme.

Berdasarkan hasil penelitian pada gambar 1 menunjukkan bahwa pola adaptasi remaja akhir terhadap kebijakan Pembatasan Sosial Berskala Besar (PSBB) adalah konformitas sebanyak $82,67 \%$ responden atau sejumlah 67 responden memilih konformitas. Sedangkan $9,33 \%$ responden atau sejumlah 7 responden memilih inovasi dan hanya $8 \%$ responden atau sejumlah 6 responden memilih retretisme. Respon ini didapatkan karena seluruh responden telah mengetahui informasi terkait pandemic corona virus ini baik proses penularan dan bahaya corona virus ini sehingga seluruh responden percaya bahwa meraka berada dalam kondisi bencana pandemi corona virus. Menurut mereka pandemi corona virus ini berbahaya dan telah banyak menimbulkan korban bencana.

\section{POLA ADAPTASI REMAJA AKHIR TERHADAP KEBIJAKAN PSBB}

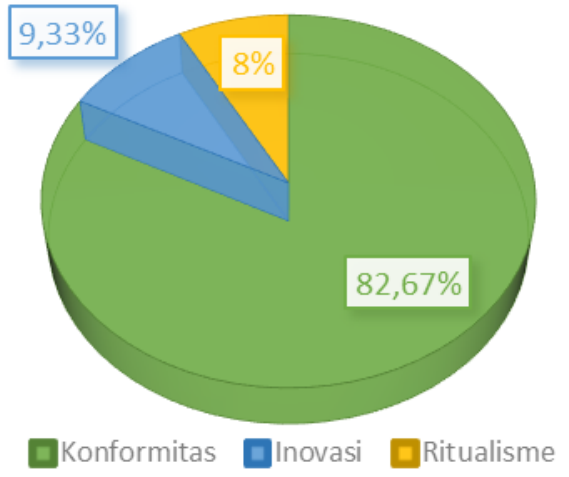

Gambar 1. Diagram Pola Adaptasi Remaja Akhir Terhadap Kebijakan PSBB

\section{Konformitas}

Responden yang memilih bersikap konformitas sangat dominan yaitu sebanyak $82,67 \%$. Hal ini menunjukkan bahwa remaja akhir menerima kebijakan Pembatasan Sosial Berskala Besar (PSBB) baik tujuan maupun caranya. Tujuan kebijakan Pembatasan Sosial Berskala Besar (PSBB) sebagai perlindungan dan antipasi bencana corona virus sangat disetujui oleh remaja akhir. Reaksi ini terjadi karena responden remaja akhir tahu tentang bagaimana penyebaran virus covid-19. Selain itu mereka juga mengetahui bahwa penularan virus covid-19 dapat dicegah dengan pembatasan sosial dan fisik antar individu. Hal ini yang membuat responden remaja akhir menerima tujuan dari kebijakan Pembatasan Sosial Berskala Besar (PSBB). Begitu pula tentang cara dan Langkah kebijakan Pembatasan Sosial Berskala Besar (PSBB) seperti pengurangan aktivitas Bersama dan diluar rumah serta penerapan protokol kesehatan seperti penggunaan masker dan mencuci tangan.

\section{Inovasi}

Responden remaja akhir selain bersikap konformitas, sebanyak 9,33\% menunjukkan sikap inovasi dalam adaptasi terhadap kebijakan Pembatasan Sosial Berskala Besar (PSBB). Responden setuju dan menerima bahwa kebijakan 
Pembatasan Sosial Berskala Besar (PSBB) bertujuan untuk perlindungan dan antisipasi terhadap bencana virus corona tetapi responden yang bersikap inovatif kurang setuju cara pembatasan fisik dan sosial dan aktivitas di luar, tetapi mereka setuju tentang cara protokol corona virus seperti penggunaan masker dan handsanitizer. Menurut mereka peningkatan imunitas, pola hidup bersih dan penggunaan protokol corona virus menjadi salah satu pemikiran dan sikap mereka tanpa harus pengurangan aktivitas diluar rumah.

\section{Ritualisme}

Responden remaja akhir sebanyak $8 \%$ nya memilih bersikap ritualisme. Sikap yang ditunjukkan pada responden remaja akhir terhadap kebijakan Pembatasan Sosial Berskala Besar (PSBB) adalah kurang setuju, kekurang setujuan ini terjadi karena efektivitas dari kebijakan Pembatasan Sosial Berskala Besar (PSBB) itu sendiri. Menurut responden remaja akhir efektivitas penerapan kebijakan ini cukup kecil sehingga tidak mampu menjadi proteksi bagi masyrakat, selain itu responden remaja akhir ini tidak menyukai apabila kegiatan dan aktivitas di luar mereka dibatasi. Namun mereka tetap mengikuti cara penerapan kebijakan Pembatasan Sosial Berskala Besar (PSBB). Hal ini dikarenakan lingkungan masyarakat mereka menerapkan dan mematuhi kebijakan Pembatasan Sosial Berskala Besar (PSBB). Mereka tetap melaksanakan pembatasan sosial dan fisik seperti masyrakat lainnya walapun dengan kondisi terpaksa.

\section{Faktor Yang Berpotensi Menimbulkan Penyimpangan}

Terdapat beberapa faktor yang berpotensi merubah sikap para remaja akhir dalam beradaptasi terhadap kebijakan Pembatasan Sosial Berskala Besar (PSBB). Faktor-faktor ini dapat mengubah persepsi reponden remaja akhir terhadap kebijakan Pembatasan Sosial Berskala Besar (PSBB) baik tujuan maupun caranya.

\section{Konformitas}

Responden remaja akhir yang memilih konformitas akan melakukan Tindakan penyimpangan terhadap terhadap kebijakan Pembatasan Sosial Berskala Besar (PSBB) apabila berkaitan dengan faktor ekonomi. Faktor ekonomi keluarga yang terkait dengan pemenuhan kebutuhan primer mulai dari sandang, pangan, papan, Pendidikan dan Kesehatan apabila tidak dapat terpenuhi oleh keluarganya dan tidak mendapatkan bantuan dari pemerintah atau pihak lain. Responden remaja tingkat akhir ini akan melakukan penyimpangan seperti beraktivitas di luar rumah, walaupun mereka tetap setuju dengan tujuan dari terhadap kebijakan Pembatasan Sosial Berskala Besar (PSBB), mereka tetap akan melanggar cara penerapan kebijakan Pembatasan Sosial Berskala Besar (PSBB) untuk membantu pemenuhan kebutuhan dasar keluarganya.

\section{Inovasi}

Inovasi, pada responden remaja akhir yang memilih sikap inovasi terhadap terhadap kebijakan Pembatasan Sosial Berskala Besar (PSBB), mereka sudah mengalami penyimpangan pada cara penerapan kebijakan Pembatasan Sosial Berskala Besar (PSBB). Faktor yang membuat mereka melakukan penyimpangan ini adalah kegiatan olahraga. Berdasarkan permenkes no 9 tahun 2020 pembatasan kegiatan sosial dan budaya adalah pembatasan kegiatan olahraga. Mereka akan tetap mengisi kegiatan olahraga seperti bersepeda, bulutangkis, jogging dan lain sebagainya walaupun dilarang. Kegiatan olahraga membuat menjadi produktif dan aktif sehingga mampu meningkatkan imun tubuh yang akan memperkecil penyebaran virus corona. 


\section{Ritualisme}

Faktor atau kegiatan yang dapat berpotensi membuat penyimpangan pada responden remaja akhir yang bersikap ritualisme terhadap kebijakan Pembatasan Sosial Berskala Besar (PSBB) adalah efektivitas penerapan kebijakan Pembatasan Sosial Berskala Besar (PSBB). Penerapan baik pelaksanaan maupun sanksi bagi yang melanggar apabila diberlakukan dengan tegas maka responden remaja akhir akan tetap mematuhi cara penerapan kebijakan Pembatasan Sosial Berskala Besar (PSBB) tetapi sebaliknya apabila pelaksanaan dan sanksi bagi yang melanggar tidak dilaksanakan dengan tegas dan menyeluruh maka responden remaja akhir akan tidak mengindahkan cara penerapan kebijakan Pembatasan Sosial Berskala Besar (PSBB).

\section{SIMPULAN}

Berdasarkan hasil penelitian dapat disimpulkan bahwa :

1. Bahwa seluruh responden mempunyai persepsi positif terhadap pembatasan sosial berskala besar (PSBB), hal ini terlihat dari hasil dominasi responden remaja akhir yang memilih konformitas dan hanya sedikit yang memilih inovasi dan ritualisme, serta tidak ada responden yang berpresepsi negatif dengan memilih retreatisme atau rebelion.

2. Potensi penyimpangan akan terjadi apabila terjadi tiga faktor yaitu faktor terkait faktor ekonomi untuk pemenuhan kebutuhan hidup, keinginan untuk berolahraga dan efektivitas penerapan pembatasan sosial berskala besar (PSBB)

\section{DAFTAR PUSTAKA}

Alexander, David. 2013. Resilience and Disaster Risk Education: an etymological journey. Natural Hazards and Earth System Sciences Discussions 1 (2), HIm. 1257-1284.

Fatmawaty, Riryn. 2017. Memahami Psikologi Remaja. Jurnal Reforma Vol. VI No. 02, Lamongan : Unisula, HIm. 56-57

Kementrian Kesehatan. (2020). Peraturan Menkes tentang Pedoman Pembatasan Sosial Berskala Besar Dalam Rangka Penanganan Corona Virus Disease (Permenkes Nomor 9 Tahun 2020). Jakarta

Merton, R.K. (1968). Social Theory and Social Structure. New York: Free Press.

Nawarko, J.Dwi dan Bagong Suyanto. 2005. Sosiologi Teks Pengantar dan Terapan. Jakarta:Prenada Media Group

Wulandari, Ade.2014. Karakteristik Pertumbuhan Perkembangan Remaja Dan Implikasinya Terhadap Masalah Kesehatan Dan Keperawatannya. Jurnal Keperawatan Anak. Volume 2, No. 1, Mei 2014. HIm 40-41

Ritzer, George. \& Goodman, J. Douglas. 2004. Teori Sosiologi Modern. Jakarta: Prenada Media Group. 